\title{
Clinicopathological characteristics of thyroid cancer misdiagnosed by fine needle aspiration
}

\author{
HIDEKI MAEDA $^{1}$, GORO KUTOMI ${ }^{1}$, FUKINO SATOMI ${ }^{1}$, HIROAKI SHIMA ${ }^{1}$, \\ MITSURU MORI $^{2}$, KOICHI HIRATA ${ }^{1}$ and ICHIRO TAKEMASA ${ }^{1}$ \\ ${ }^{1}$ Department of Surgery, Surgical Oncology and Science, Sapporo Medical University, Sapporo, Hokkaido 060-8543; \\ ${ }^{2}$ Department of Public Health, Sapporo Medical University, Sapporo, Hokkaido 060-8556, Japan
}

Received March 3, 2015; Accepted April 6, 2016

DOI: $10.3892 /$ etm.2016.3651

\begin{abstract}
Fine-needle aspiration (FNA) is commonly used as a preoperative assessment to diagnose thyroid cancer. However, misdiagnosis of malignancy by FNA is not rare, even if image examination suggests the possibility of thyroid cancer. In the present study, the clinicopathological factors of patients whose preoperative FNA examination had not led to a diagnosis of thyroid cancer were examined. In total, 125 patients with thyroid cancer who underwent FNA and surgery (total thyroidectomy, subtotal thyroidectomy or hemithyroidectomy) at the Department of Surgery, Surgical Oncology and Science of the Sapporo Medical University Hospital between 2006 and 2013 were retrospectively analyzed. The patients were divided into two groups: Group A, malignancy determined by FNA, and group B, no malignancy. The groups were then compared by gender, age, tumor size, stage, tumor stage, lymph node metastasis, histology, surgical procedure methods, presence or absence of calcification and thyroglobulin levels. The mean age of the patients in group A (5 males and 59 females) was 53.0 years. The mean age in group B (11 males and 49 females) was 54.2 years. The mean tumor size in both groups was $1.6 \mathrm{~cm}$. The mean thyroglobulin levels were $82.7 \mathrm{ng} / \mathrm{ml}$ in Group A and $525.5 \mathrm{ng} / \mathrm{ml}$ in group B. There were also significant differences between the groups for tumor stage $(\mathrm{P}=0.046)$, histological type $(\mathrm{P}=0.024)$ and thyroglobulin levels $(\mathrm{P}=0.035)$. The results of the present study suggested that it may be difficult to diagnose thyroid cancer by FNA in cases with non-papillary carcinoma and higher thyroglobulin levels.
\end{abstract}

Correspondence to: Dr Goro Kutomi, Department of Surgery, Surgical Oncology and Science, Sapporo Medical University, South 1 West 16, Chuo-ku, Sapporo, Hokkaido 060-8543, Japan E-mail: kutomi@sapmed.ac.jp

Key words: thyroid cancer, fine needle aspiration, calcification, thyroglobulin, clinicopathological factors

\section{Introduction}

Fine-needle aspiration (FNA) is the most commonly used method for the preoperative assessment of thyroid nodules. FNA provides important information with regard to the most suitable surgical treatment, and the routine use of FNA has reduced the number of unnecessary surgical procedures for thyroid nodules. The American Thyroid Association guidelines state that FNA should be used as one of the initial diagnostic tests due to its high diagnostic reliability and cost-effectiveness. However, false-negative rates are generally reported to be $3.6-10.2 \%$ (1-4). The method provides diagnostically useful results in $\sim 80 \%$ of cases, and its sensitivity and specificity have been reported to be 83 and $92 \%$, respectively (5). In the present study, the clinicopathological characteristics of thyroid cancers that were misdiagnosed by FNA were compared and a retrospective follow-up study of the patients who underwent surgery for thyroid cancer was performed.

\section{Patients and methods}

Patients. A total of 125 patients with thyroid cancer treated at the Department of Surgery, Surgical Oncology and Science of the Sapporo Medical University Hospital (Sapporo, Japan) between April 2006 and April 2013 were retrospectively analyzed in the present study. Patients with thyroid cancer were eligible for inclusion in the present study if they had been treated with total thyroidectomy, subtotal thyroidectomy or hemithyroidectomy. The patients who underwent FNA and surgical treatment had been pathologically diagnosed with thyroid cancer using general rules for the description of thyroid tumors (6). All FNAs had been performed with the guidance of ultrasound, using a $22 \mathrm{G}$ needle attached to a $20 \mathrm{ml}$ disposable plastic syringe and aspirator with hand-free techniques.

The present study was performed according to the Ethical Guidelines for Clinical Research of the Japanese Ministry of Health, Labor and Welfare. An independent ethics committee for each participating site approved the protocol and any modifications. Written informed consent was obtained from all patients or the patient's family. 
Experiments. Thyroglobulin levels were measured using an electrochemiluminescence assay (Elecsys ${ }^{\circledR} \mathrm{Tg}$ II, Roche Diagnostics International AG, Rotkreuz, Switzerland), and calcification within the thyroid gland was detected using ultrasonography or computed tomography. The clinical information of the patients obtained from their medical records is presented in Table I. Smears had been fixed in 95\% methanol while still wet and stained using standard Papanicolaou stains. The presence or absence of calcification (both micro and macro) had been determined by ultrasonography or computed tomography.

Groups. The patients were divided into two groups according to the Papanicolaou Society of Cytopathology classification system for FNA specimens: Group A $(n=64)$ contained patients diagnosed with thyroid cancer by FNA, and group B $(n=61)$ consisted of the patients with no malignancy, as determined by FNA.

Statistical analyses. The clinicopathological characteristics of thyroid cancer in both groups were retrospectively analyzed using SAS 9.4 software (SAS Institute, Tokyo, Japan). Comparisons of clinicopathological characteristics between the different subgroups were performed using an independent-samples t-test and $\chi^{2}$ test. Variables with statistical significance in the univariate analysis were investigated by multivariate analysis. In addition, odds ratios and 95\% confidence intervals were estimated. All P-values were two-sided and considered statistically significant if $<0.05$.

\section{Results}

Patient demographics. The characteristics of the 125 patients who received surgical treatment for thyroid cancer are presented in Table I. The mean ages of the patients in groups A and B were 53.0 and 54.2 years, respectively. Group A included 5 males and 59 females, and group B included 11 males and 49 females. Women were therefore predominant in both groups.

Postoperative pathological characteristics. Papillary carcinoma was the primary histological type identified, accounting for the majority of patients in both groups (62 patients in group $\mathrm{A}$ and 50 patients in group $\mathrm{B}$ ). The characteristics of the patients (age, gender, tumor size, tumor stage, lymph node metastasis, histology, surgical method, calcification and thyroglobulin levels) in groups A and B were analyzed using a $\chi^{2}$ test. Statistically significant differences between the two groups were observed for stage $(\mathrm{P}=0.046)$, histology $(\mathrm{P}=0.024)$ and mean thyroglobulin levels $(\mathrm{P}=0.035)$.

Similarly, when the patients were divided into two subgroups according to the presence or absence of calcification, a significant difference was observed between the two subgroups only for gender (Table II).

The thyroglobulin levels were also analyzed by dividing the patients into two subgroups (Table III). Significant statistical differences were observed between the two groups for stage $(P=0.008)$, tumor size $(P=0.025)$, histology $(P=0.004)$ and surgical methods $(\mathrm{P}=0.009)$. Independent-samples t-tests were performed to compare the patients of group A with those of group B (Table IV), patients with calcification and patients without calcification (Table V), and patients with thyroglobulin levels $\geq 100$ and those with thyroglobulin levels $<100$ (Table VI).

Significant differences were observed in the preoperative thyroglobulin levels between patients of group A and patients of group B, in age between the patients with calcification with calcification and those without, and in tumor size between patients with preoperative thyroglobulin levels $\geq 100 \mathrm{ng} / \mathrm{ml}$ and those with preoperative thyroglobulin levels $<100 \mathrm{ng} / \mathrm{ml}$.

Multivariate logistic regression analysis was performed using tumor stage, histology and thyroglobulin levels as variables in groups A and B (Table VII). Histologies other than papillary carcinoma (follicular and poorly differentiated carcinoma) and preoperative serum thyroglobulin levels of $\geq 100 \mathrm{ng} / \mathrm{ml}$ were significant factors when FNA cytology did not provide evidence for malignancy.

\section{Discussion}

The high incidence of thyroid nodules has been well-established. Thyroid nodules can be discovered by ultrasonography in over half of all patients, even if the sizes of the nodules are small (7). Patients frequently detect the nodule themselves by noticing a neck mass, and the nodules can also be detected by cervical palpation in a health checkup, or by chest computed tomography performed for the assessment of diseases other than thyroid diseases (8). Furthermore, the frequency of carotid ultrasonography as a routine examination to search for arteriosclerosis is now increasing, and thus small and/or clinically insignificant thyroid nodules are also incidentally detected (9).

When an ultrasonography reveals the presence of thyroid nodules, FNA cytology is often performed (10). However, performing FNA cytology for all nodules is impractical. At the Department of Surgery, Surgical Oncology and Science of the Sapporo Medical University Hospital a 'wait-and-see' strategy is applied for cases of thyroid nodules measuring $\leq 5 \mathrm{~mm}$ in diameter, those measuring 6-10 $\mathrm{mm}$ that appear benign on ultrasound, and those measuring 11-20 $\mathrm{mm}$ that are apparently cysts. Therefore, nodules that should be targeted for cytology include those measuring 6-10 $\mathrm{mm}$ that are suspected cases of papillary carcinoma, those measuring 11-20 $\mathrm{mm}$ that are suspected of being solid masses, and those measuring $\geq 21 \mathrm{~mm}$.

Papillary carcinoma, which is easy to diagnose on ultrasound, accounts for $90 \%$ of all cases of thyroid cancer (11). The ultrasound features of typical papillary carcinoma include an irregular shape, ill-defined margins, a low echoic content, and frequent minute calcification inside the carcinoma $(12,13)$. However, as some papillary carcinomas have a regular shape and are difficult to differentiate from follicular tumors and adenomatous goiter, caution is required (14). In those cases, FNA has the advantage that it can easily be repeated if necessary (13). A previous study reported that it may be advantageous to perform repeated procedures (15). During FNA, a low echoic portion of the irregular inner echoic content is targeted, and a tissue sample is cut with a needle tip and removed by suction in order to obtain a cell mass (16). It has been reported that $92.5 \%$ of thyroid cancers are papillary cancer in Japan (17). Therefore, if thyroid nodules are diagnosed by FNA cytology to be malignant or are suspected of being malignant, they are 
Table I. Comparison of the cytology results.

\begin{tabular}{|c|c|c|c|c|c|}
\hline \multirow[b]{2}{*}{ Variable } & \multicolumn{2}{|c|}{ Group A } & \multicolumn{2}{|c|}{ Group B } & \multirow[b]{2}{*}{ P-value } \\
\hline & Number (mean) & $\mathrm{SD}(\%)$ & Number (mean) & $\mathrm{SD}(\%)$ & \\
\hline Age (years) & 53.0 & 14.3 & 54.2 & 17.3 & 0.669 \\
\hline \multicolumn{6}{|l|}{ Gender } \\
\hline Male & 5 & 7.8 & 11 & 18.3 & 0.081 \\
\hline Female & 59 & 92.2 & 49 & 81.7 & \\
\hline Tumor size $(\mathrm{cm})$ & 1.6 & 0.7 & 1.6 & 1.1 & 0.754 \\
\hline \multicolumn{6}{|l|}{ Stage } \\
\hline $\mathrm{I}$ & 30 & 46.9 & 31 & 52.5 & 0.046 \\
\hline II & 1 & 1.6 & 1 & 1.7 & \\
\hline III & 20 & 31.2 & 18 & 30.5 & \\
\hline IVA & 13 & 20.3 & 4 & 6.8 & \\
\hline IVC & 0 & 0.0 & 5 & 8.5 & \\
\hline \multicolumn{6}{|l|}{ Tumor stage } \\
\hline T1a & 16 & 25.0 & 20 & 33.3 & 0.218 \\
\hline $\mathrm{T} 1 \mathrm{~b}$ & 18 & 28.1 & 10 & 16.7 & \\
\hline $\mathrm{T} 2$ & 8 & 12.5 & 4 & 6.7 & \\
\hline T3 & 21 & 32.8 & 22 & 36.7 & \\
\hline $\mathrm{T} 4 \mathrm{a}$ & 1 & 1.6 & 4 & 6.7 & \\
\hline \multicolumn{6}{|l|}{ Lymph node metastasis } \\
\hline No & 19 & 29.7 & 25 & 41.7 & 0.306 \\
\hline N1a & 25 & 39.1 & 22 & 36.7 & \\
\hline N1b & 20 & 31.2 & 10 & 16.7 & \\
\hline NX & 0 & 0.0 & 3 & 5.0 & \\
\hline \multicolumn{6}{|l|}{ Histology } \\
\hline Papillary & 62 & 96.9 & 50 & 82.0 & 0.024 \\
\hline Follicular & 1 & 1.6 & 6 & 9.8 & \\
\hline Poorly & 1 & 1.6 & 5 & 8.2 & \\
\hline \multicolumn{6}{|l|}{ Operation methods } \\
\hline Hemi-Tx & 23 & 35.9 & 19 & 31.7 & 0.86 \\
\hline Subtotal-Tx & 17 & 26.6 & 18 & 30.0 & \\
\hline Total-Tx & 24 & 37.5 & 23 & 38.3 & \\
\hline \multicolumn{6}{|l|}{ Calcification } \\
\hline+ & 25 & 39.7 & 17 & 27.9 & 0.165 \\
\hline- & 38 & 60.3 & 44 & 72.1 & \\
\hline Thyroglobulin (ng/ml) & 82.7 & 284.3 & 525.5 & 1626.1 & 0.035 \\
\hline
\end{tabular}

Tx, Thyroidectomy; SD, standard deviation.

usually diagnosed as papillary carcinoma. When patients are suspected of having papillary carcinoma, they are regarded as candidates for surgery (18).

Thyroglobulin is a thyroid-specific protein secreted by the thyroid follicles. Papillary and follicular carcinoma cells also produce thyroglobulin (19). However, thyroglobulin is also secreted by follicular adenoma and adenomatous goiter, which are benign diseases, and serum levels of thyroglobulin are also elevated in Basedow's and Hashimoto's diseases (20). Therefore, serum thyroglobulin levels cannot be used to reliably differentiate between benign and malignant lesions (21). Guidelines for the treatment of thyroid tumors include similar treatments to those used for nodular goiter (22). The guidelines describe abnormally high serum levels of thyroglobulin $(\geq 1,000 \mathrm{ng} / \mathrm{ml})$ as a surgical indication established by consensus of the guideline committee. When there is no recurrence of the tumor following total thyroidectomy, thyroglobulin levels decrease below detectable levels (23). Therefore, thyroglobulin is a useful marker for the recurrence of differentiated thyroid cancer.

In the present study, the clinicopathological factors of patients for whom preoperative FNA cytology did not provide evidence of malignancy were examined. The results revealed 
Table II. Comparison of the presence or absence of thyroid calcification.

\begin{tabular}{|c|c|c|c|c|c|}
\hline \multirow[b]{2}{*}{ Variable } & \multicolumn{2}{|c|}{ Calcification (+) } & \multicolumn{2}{|c|}{ Calcification (-) } & \multirow[b]{2}{*}{ P-value } \\
\hline & Number (mean) & $\mathrm{SD}(\%)$ & Number (mean) & $\mathrm{SD}(\%)$ & \\
\hline \multicolumn{6}{|l|}{ Gender } \\
\hline Male & 15 & 16.7 & 1 & 2.2 & 0.010 \\
\hline Female & 68 & 83.3 & 44 & 97.8 & \\
\hline \multicolumn{6}{|l|}{ Stage } \\
\hline I & 36 & 43.9 & 26 & 57.8 & 0.202 \\
\hline II & 1 & 1.2 & 1 & 2.2 & \\
\hline III & 27 & 32.9 & 11 & 24.4 & \\
\hline IVA & 11 & 13.4 & 7 & 15.6 & \\
\hline IVC & 7 & 8.5 & 0 & 0.0 & \\
\hline \multicolumn{6}{|l|}{ Tumor stage } \\
\hline T1a & 24 & 28.9 & 14 & 31.1 & 0.796 \\
\hline $\mathrm{T} 1 \mathrm{~b}$ & 16 & 19.3 & 12 & 26.7 & \\
\hline $\mathrm{T} 2$ & 10 & 12.1 & 4 & 8.9 & \\
\hline T3 & 29 & 34.9 & 14 & 31.1 & \\
\hline $\mathrm{T} 4 \mathrm{a}$ & 4 & 4.8 & 1 & 2.2 & \\
\hline \multicolumn{6}{|c|}{ Tumor size $(\mathrm{cm})$} \\
\hline$<1.0$ & 21 & 25.0 & 12 & 26.7 & 0.565 \\
\hline $1.0 \sim 1.9$ & 35 & 41.7 & 22 & 48.9 & \\
\hline$\geqq 2.0$ & 28 & 33.3 & 11 & 24.4 & \\
\hline \multicolumn{6}{|c|}{ Lymph node metastasis } \\
\hline No & 29 & 34.9 & 18 & 40.0 & 0.852 \\
\hline N1a & 32 & 38.6 & 16 & 35.6 & \\
\hline N1b & 20 & 24.1 & 10 & 22.2 & \\
\hline NX & 2 & 2.4 & 1 & 2.2 & \\
\hline \multicolumn{6}{|l|}{ Histology } \\
\hline Papillary & 72 & 85.7 & 42 & 93.3 & 0.398 \\
\hline Follicular & 6 & 7.1 & 2 & 4.4 & \\
\hline Poorly & 6 & 7.1 & 1 & 2.2 & \\
\hline \multicolumn{6}{|c|}{ Operation methods } \\
\hline Hemi-Tx & 24 & 28.9 & 20 & 44.4 & 0.103 \\
\hline Subtotal-Tx & 22 & 26.5 & 13 & 28.9 & \\
\hline Total-Tx & 37 & 44.6 & 12 & 26.7 & \\
\hline \multicolumn{6}{|c|}{ Thyroglobulin (ng/ml) } \\
\hline$<50.0$ & 44 & 53.7 & 28 & 62.2 & 0.578 \\
\hline $50.0-99.9$ & 13 & 15.8 & 7 & 15.7 & \\
\hline$\geqq 100.0$ & 25 & 30.5 & 10 & 22.2 & \\
\hline
\end{tabular}

Tx, Thyroidectomy; SD, standard deviation.

that histology other than papillary carcinoma (follicular and poorly differentiated carcinoma) and preoperative thyroglobulin levels of $\geq 100 \mathrm{ng} / \mathrm{ml}$ were significant factors in misdiagnosis by FNA. Kitagawa et al (21) reported that, according to the FNA classification, cytology specimens were 'malignant' in $99.7 \%$ of specimens, 'suspected of malignancy' in $93.3 \%$, 'indeterminate' in $42.4 \%$, 'benign' in $8.8 \%$ and 'inadequate' in $33.3 \%$. The authors also described the association between the FNA classification and histopathological diagnosis confirmed by surgery (21). A total of 44 specimens were diagnosed as benign by cytology and malignant by histopathology, and 24/44 specimens $(54.5 \%)$ were identified as follicular carcinoma $(24,25)$.

In this study, the patients were classified according to the Papanicolaou Society of Cytopathology classification system for FNA samples into group A, including only patients with 'malignant' specimens, and group B, including only patients with specimens that were 'suspected of malignancy,' 'indeterminate,' 'normal or benign,' or 'inadequate.' Of the 112 patients 
Table III. Comparison of the preoperative thyroglobulin levels.

\begin{tabular}{|c|c|c|c|c|c|}
\hline \multirow[b]{2}{*}{ Variable } & \multicolumn{2}{|c|}{ Thyroglobulin $\geqq 100 \mathrm{ng} / \mathrm{ml}$} & \multicolumn{2}{|c|}{ Thyroglobulin $<100 \mathrm{ng} / \mathrm{ml}$} & \multirow[b]{2}{*}{ P-value } \\
\hline & Number (mean) & $\mathrm{SD}(\%)$ & Number (mean) & $\mathrm{SD}(\%)$ & \\
\hline \multicolumn{6}{|l|}{ Gender } \\
\hline Male & 4 & 11.4 & 11 & 11.7 & 0.966 \\
\hline Female & 31 & 88.6 & 83 & 88.3 & \\
\hline \multicolumn{6}{|l|}{ Stage } \\
\hline I & 16 & 45.7 & 48 & 51.6 & 0.008 \\
\hline II & 0 & 0.0 & 2 & 2.2 & \\
\hline III & 10 & 28.6 & 28 & 30.1 & \\
\hline IVA & 3 & 8.6 & 14 & 15.0 & \\
\hline IVC & 6 & 17.1 & 1 & 1.1 & \\
\hline \multicolumn{6}{|l|}{ Tumor stage } \\
\hline T1a & 8 & 22.9 & 30 & 31.9 & 0.089 \\
\hline $\mathrm{T} 1 \mathrm{~b}$ & 4 & 11.4 & 25 & 26.6 & \\
\hline $\mathrm{T} 2$ & 7 & 20.0 & 7 & 7.5 & \\
\hline T3 & 14 & 40.0 & 29 & 30.8 & \\
\hline $\mathrm{T} 4 \mathrm{a}$ & 2 & 5.7 & 3 & 3.2 & \\
\hline \multicolumn{6}{|c|}{ Tumor size $(\mathrm{cm})$} \\
\hline$<1.0$ & 8 & 22.9 & 25 & 26.6 & 0.025 \\
\hline $1.0 \sim 1.9$ & 10 & 28.6 & 46 & 48.9 & \\
\hline$\geq 2.0$ & 17 & 48.6 & 23 & 24.5 & \\
\hline \multicolumn{6}{|c|}{ Lymph node metastasis } \\
\hline No & 16 & 45.7 & 31 & 33.0 & 0.324 \\
\hline N1a & 10 & 28.6 & 39 & 41.5 & \\
\hline N1b & 9 & 25.7 & 21 & 22.3 & \\
\hline NX & 0 & 0.0 & 3 & 3.2 & \\
\hline \multicolumn{6}{|l|}{ Histology } \\
\hline Papillary & 26 & 74.3 & 88 & 93.6 & 0.004 \\
\hline Follicular & 6 & 17.1 & 2 & 2.1 & \\
\hline Poorly & 3 & 8.6 & 4 & 4.3 & \\
\hline \multicolumn{6}{|c|}{ Operation methods } \\
\hline Hemi-Tx & 9 & 35.9 & 35 & 37.2 & 0.009 \\
\hline Subtotal-Tx & 5 & 26.6 & 30 & 31.9 & \\
\hline Total-Tx & 21 & 37.5 & 29 & 30.9 & \\
\hline \multicolumn{6}{|l|}{ FNA } \\
\hline Others & 23 & 71.9 & 37 & 40.7 & 0.002 \\
\hline ClassV & 9 & 28.1 & 54 & 59.3 & \\
\hline \multicolumn{6}{|l|}{ Calcification } \\
\hline- & 10 & 28.6 & 35 & 38.0 & 0.319 \\
\hline+ & 25 & 71.4 & 57 & 62.0 & \\
\hline
\end{tabular}

Tx, Thyroidectomy; SD, standard deviation.

with papillary carcinoma, 62 had been diagnosed as having malignant lesions by cytology.

For other histological types, 1/7 patients with follicular carcinoma and 1/6 patients with anaplastic carcinoma were diagnosed with malignant lesions by cytology; and therefore the diagnostic accuracy was low. Papillary carcinoma is a malignant tumor derived from the follicular epithelium and well-differentiated adenocarcinoma with a basically papillary structure (26). Papillary carcinoma has numerous cytological features including overlapping nuclei, ground glass nuclei, nuclear grooves, and intranuclear cytoplasmic inclusions in the cancer cell nuclei that provide diagnostic evidence; thus, the diagnostic accuracy for this type of carcinoma is high (27). However, cytological abnormalities of endocrine tumors, 
Table IV. Comparison of patients with malignancy and those without (t-test results).

\begin{tabular}{lcrrrrrr}
\hline & & \multicolumn{2}{c}{ Group A } & & \multicolumn{2}{c}{ Group B } & \\
\cline { 3 - 4 } Variable & Group A/Group B & Mean & SD (\%) & & Mean & SD (\%) & P-value \\
\hline Age (years) & $64 / 60$ & 53.0 & 14.3 & & 54.2 & 17.3 & 0.669 \\
Tumor size (cm) & $64 / 61$ & 1.6 & 0.7 & 1.6 & 1.1 & 0.754 \\
Thyroglobulin (ng/ml) & $63 / 60$ & 82.7 & 284.3 & & 525.5 & $1,626.1$ & 0.035 \\
\hline
\end{tabular}

$\mathrm{SD}$, standard deviation.

Table V. Comparison of patients with calcification and those without (t-test results).

\begin{tabular}{|c|c|c|c|c|c|c|}
\hline \multirow[b]{2}{*}{ Variable } & \multirow[b]{2}{*}{$(+) /(-)$} & \multicolumn{2}{|c|}{ Calcification (+) } & \multicolumn{2}{|c|}{ Calcification (-) } & \multirow[b]{2}{*}{ P-value } \\
\hline & & Mean & $\mathrm{SD}(\%)$ & Mean & $\mathrm{SD}(\%)$ & \\
\hline Age (years) & $83 / 45$ & 56.3 & 15.9 & 50.2 & 2.3 & 0.039 \\
\hline Tumor size $(\mathrm{cm})$ & $84 / 45$ & 1.7 & 1.5 & 1.5 & 1.2 & 0.305 \\
\hline Thyroglobulin (ng/ml) & $82 / 45$ & 880.1 & $3,884.9$ & 274.9 & $1,152.8$ & 0.310 \\
\hline
\end{tabular}

$\mathrm{SD}$, standard deviation.

Table VI. Comparison of patients with high thyroglobulin levels and those with low thyroglobulin levels (t-test results).

\begin{tabular}{|c|c|c|c|c|c|c|}
\hline \multirow[b]{2}{*}{ Variable } & \multirow[b]{2}{*}{$\geqq 100 /<100$} & \multicolumn{2}{|c|}{ Thyroglobulin $\geqq 100$} & \multicolumn{2}{|c|}{ Thyroglobulin $<100$} & \multirow[b]{2}{*}{ P-value } \\
\hline & & Mean & $\mathrm{SD}(\%)$ & Mean & $\mathrm{SD}(\%)$ & \\
\hline Age (years) & $35 / 94$ & 56.8 & 16.6 & 52.7 & 15.6 & 0.195 \\
\hline Tumor size $(\mathrm{cm})$ & $35 / 94$ & 2.1 & 1.5 & 1.4 & 0.7 & 0.001 \\
\hline
\end{tabular}

$\mathrm{SD}$, standard deviation.

including thyroid cancer, are generally mild and the findings for malignant and benign cells overlap (28).

When there is a discrepancy between the cytological findings and clinical diagnosis, cytological underdiagnosis appears to be likely (29). Therefore, with the exception of patients with papillary carcinoma, which is easily diagnosed, it is speculated that numerous patients received a false negative diagnosis in which cancer was erroneously classified as benign.

In the present study, the patients were examined according to thyroglobulin levels and classified either as thyroglobulin levels of $50,50-100$, or $\geq 100 \mathrm{ng} / \mathrm{ml}$. As for the distribution of thyroglobulin levels, the median was $37.0 \mathrm{ng} / \mathrm{ml}$, and the mean was $656.3 \mathrm{ng} / \mathrm{ml}$. The patients were divided into three groups for analysis. Patients with high thyroglobulin levels may have had pathological conditions causing thyroglobulin elevation, such as chronic thyroiditis, as the background of resected thyroid glands. Lee et al (30) reported that papillary carcinoma was significantly associated with pathologically confirmed chronic thyroiditis. However, further studies are required in order to investigate this possibility.
Table VII. Multivariate analysis of tumor stage, histological type and thyroglobulin levels.

\begin{tabular}{llll}
\hline Variable & OR & $95 \%$ CI & P-value \\
\hline Stage & & & \\
$\quad$ I & 1.00 & & \\
II or III & 1.36 & $0.58-3.20$ & 0.486 \\
$\quad$ IVA or IVC & 2.70 & $0.77-9.43$ & 0.120 \\
P for trend, P=0.220 & & & \\
Histology & & & \\
$\quad$ Papillary & 1.00 & & \\
$\quad$ Non-papillary & 0.13 & $0.03-0.68$ & 0.015 \\
Thyroglobulin (ng/ml) & & & \\
$\quad$ <50.0 & 1.00 & & 0.147 \\
50.0-99.9 & 0.45 & $0.16-1.32$ & 0.007 \\
$\quad$ 100.0 & 0.26 & $0.10-0.69$ & \\
\hline
\end{tabular}

$\mathrm{SD}$, standard deviation; OR, odds ratio; CI, confidence interval. 
In conclusion, for the differential diagnosis of thyroid masses, FNA cytology is an essential diagnostic procedure and provides important information which regards to the suitability of surgical treatment. As cases with thyroid masses other than those with papillary carcinoma are often difficult to diagnose by cytology, these masses should be comprehensively assessed based on the combined results of both cytological and image diagnoses.

\section{Acknowledgements}

The present study was supported by a grant from the Yuasa Memorial Foundation. The authors are grateful to all study participants.

\section{References}

1. Bohacek L, Milas M, Mitchell J, Siperstein A and Berber E: Diagnostic accuracy of surgeon-performed ultrasound-guided fine-needle aspiration of thyroid nodules. Ann Surg Oncol 19: 45-51, 2012.

2. Lew JI, Snyder RA, Sanchez YM and Solorzano CC: Fine needle aspiration of the thyroid: Correlation with final histopathology in a surgical series of 797 patients. J Am Coll Surg 213: 188-194, 2011.

3. Gul K, Ersoy R, Dirikoc A, Korukluoglu B, Ersoy PE, Aydin R, Ugras SN, Belenli OK and Cakir B: Ultrasonographic evaluation of thyroid nodules: Comparison of ultrasonographic, cytological, and histopathological findings. Endocrine 36: 464-472, 2009.

4. Yang J, Schnadig V, Logrono R and Wasserman PG: Fine-needle aspiration of thyroid nodules: A study of 4703 patients with histologic and clinical correlations. Cancer 111: 306-315, 2007.

5. Gharib H, Papini E, Valcavi R, Baskin HJ, Crescenzi A, Dottorini ME, Duick DS, Guglielmi R, Hamilton CR Jr, Zeiger MA and Zini M; AACE/AME Task Force on Thyroid Nodules: American Association of Clinical Endocrinologists and Associazione Medici Endocrinologi medical guidelines for clinical practice for the diagnosis and management of thyroid nodules. Endocr Pract 12: 63-102, 2006.

6. Iwase K: Outline of general rules for the description of thyroid cancer (6th edition). Nihon Rinsho 65: 1943-1951, 2007 (In Japanese).

7. Brander A, Viikinkoski P, Tuuhea J, Voutilainen L and Kivisaari L: Clinical versus ultrasound examination of the thyroid gland in common clinical practice. J Clin Ultrasound 20: 37-42, 1992.

8. Marqusee E, Benson CB, Frates MC, Doubilet PM, Larsen PR, Cibas ES and Mandel SJ: Usefulness of ultrasonography in the management of nodular thyroid disease. Ann Intern Med 133: 696-700, 2000.

9. Tan GH and Gharib H: Thyroid incidentalomas: Management approaches to nonpalpable nodules discovered incidentally on thyroid imaging. Ann Intern Med 126: 226-231, 1997.

10. Cooper DS, Doherty GM, Haugen BR, Kloos RT Lee SL, Mandel SJ, Mazzaferri EL, McIver B, Pacini F, Schlumberger M, et al; American Thyroid Association (ATA) Guidelines Taskforce on Thyroid Nodules and Differentiated Thyroid Cancer: Revised American Thyroid Association management guidelines for patients with thyroid nodules and differentiated thyroid cancer. Thyroid 11: 1167-1199, 2009.

11. Ito Y, Amino N, Yokozawa T, Ota H, Ohshita M, Murata N, Morita S, Kobayashi K and Miyauchi A: Ultrasonographic evaluation of thyroid nodules in 900 patients: Comparison among ultrasonographic, cytological and histological findings. Thyroid 17: 1269-1276, 2007.
12. Solbiati L, Volterrani L, Rizzatto G, Bazzocchi M, Busilacci P, Candiani F, Ferrari F, Giuseppetti G, Maresca G and Mirk P: The thyroid gland with low uptake lesions: Evaluation by ultrasound. Radiology 155: 187-191, 1985.

13. Weber AL, Randolph G and Aksoy FG: The thyroid and parathyroid glands. CT and MR imaging and correlation with pathology and clinical findings. Radiol Clin North Am 38: 1105-1129, 2000.

14. Iannuccilli JD, Cronan JJ and Monchik JM: Risk for malignancy of thyroid nodules as assessed by sonographic criteria: The need for biopsy. J Ultrasound Med 23: 1455-1464, 2004.

15. Alexander EK, Heering JP, Benson CB, Frates MC, Doubilet PM, Cibas ES and Marqusee E: Assessment of nondiagnostic ultrasound-guided fine needle aspirations of thyroid nodules. J Clin Endocrinol Metab 87: 4924-4927, 2002.

16. Baskin HJ: Ultrasound-guided fine-needle aspiration biopsy of thyroid nodules and multinodular goiters. Endocr Pract 10: 242-245, 2004.

17. Iwasaki H: The latest data about the epidemiology of thyroid cancer. Rinshogeka 62: 39-46, 2007 (In Japanese).

18. Hamming JF, Goslings BM, van Steenis GJ, van Ravenswaay Claasen H, Hermans J and van de Velde CJ: The value of fine-needle aspiration biopsy in patients with nodular thyroid disease divided into groups of suspicion of malignant neoplasms on clinical grounds. Arch Intern Med 150: 113-116, 1990.

19. Lin JD: Thyroglobulin and human thyroid cancer. Clin Chim Acta 388: 15-21, 2008.

20. Pacini F, Pinchera A, Giani C, Grasso L, Doveri F and Baschieri L: Serum thyroglobulin in thyroid carcinoma and other thyroid disorders. J Endocrinol Invest 3: 283-292, 1980.

21. Kitagawa $\mathrm{W}$ and Ito K: Fine needle aspiration cytology. Nihon Rinsho 69 (Suppl 2): S320-S323, 2011 (In Japanese).

22. Takami H, Ito Y, Okamoto T and Yoshida A: Therapeutic strategy for differentiated thyroid carcinoma in Japan based on a newly established guideline managed by Japanese Society of Thyroid Surgeons and Japanese Association of Endocrine Surgeons. World J Surg 35: 111-121, 2011.

23. Ozata M, Suzuki S, Miyamoto T, Liu RT, Fierro-Renoy F and DeGroot LJ: Serum thyroglobulin in the follow-up of patients with treated differentiated thyroid cancer. J Clin Endocrinol Metab 79: 98-105, 1994.

24. Cooper DS, Doherty GM, Haugen BR, Kloos RT, Lee SL, Mandel SJ, Mazzaferri EL, McIver B, Sherman SI and Tuttle RM; American Thyroid Association Guidelines Taskforce: Management guidelines for patients with thyroid nodules and differentiated thyroid cancer. Thyroid 16: 109-142, 2006.

25. Sugino K, Ito K, Nagahama M, Kitagawa W, Shibuya $H$, Ohkuwa K, Yano Y, Uruno T, Akaishi J, Suzuki A, et al: Diagnostic accuracy of fine needle aspiration biopsy cytology and ultrasonography in patients with thyroid nodules diagnosed as benign or indeterminate before thyroidectomy. Endocr J 60: 375-382, 2013.

26. Fonseca E1, Soares P, Cardoso-Oliveira $M$ and Sobrinho-Simões M: Diagnostic criteria in well-differentiated thyroid carcinomas. Endocr Pathol 17: 109-117, 2006.

27. Hirokawa M, Maekawa M, Kuma S and Miyauchi A: Cribriform-morular variant of papillary thyroid carcinoma - cytological and immunocytochemical findings of 18 cases. Diagn Cytopathol 38: 890-896, 2010.

28. Lloyd RV, Buehler D and Khanafshar E: Papillary Thyroid Carcinoma Variants. Head Neck Pathol 5: 51-56, 2011

29. Ito Y, Kihara M, Takamura Y, Kobayashi K, Miya A, Hirokawa M and Miyauchi A: Prognosis and prognostic factors of papillary thyroid carcinoma in patients under 20 years. Endocr J 59: 539-545, 2012.

30. Lee JH, Kim Y, Choi JW and Kim YS: The association between papillary thyroid carcinoma and histologically proven Hashimoto's thyroiditis: A meta-analysis. Eur J Endocrinol 168: 343-349, 2013. 